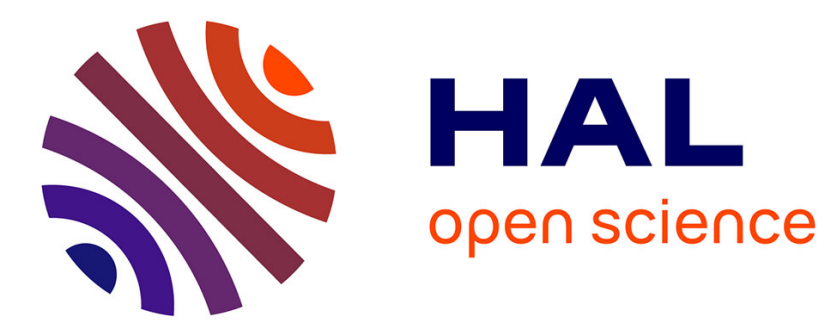

\title{
Radiative environments and thermal comfort in temperate climate
}

\author{
$\mathrm{X}$. Berger
}

\section{To cite this version:}

X. Berger. Radiative environments and thermal comfort in temperate climate. Revue de Physique Appliquée, 1986, 21 (11), pp.717-726. 10.1051/rphysap:019860021011071700 • jpa-00245492

\section{HAL Id: jpa-00245492 https://hal.science/jpa-00245492}

Submitted on 1 Jan 1986

HAL is a multi-disciplinary open access archive for the deposit and dissemination of scientific research documents, whether they are published or not. The documents may come from teaching and research institutions in France or abroad, or from public or private research centers.
L'archive ouverte pluridisciplinaire HAL, est destinée au dépôt et à la diffusion de documents scientifiques de niveau recherche, publiés ou non, émanant des établissements d'enseignement et de recherche français ou étrangers, des laboratoires publics ou privés. 
Classification

Physics Abstracts

$44.00-44.10-44.25-44.90$

\title{
Radiative environments and thermal comfort in temperate climate
}

\author{
X. Berger \\ C.N.R.S., Centre de Bâtiments Solaires à Sophia Antipolis, B.P. 21, 06561 Valbonne Cedex, France
}

(Reçu le 12 mai 1986, révisé le 17 juillet, accepté le 29 juillet 1986)

\begin{abstract}
Résumé. - La modélisation d'un volume habitable pose le problème du confort thermique de l'être humain. Les ambiances radiativement déséquilibrées peuvent correspondre physiologiquement et psychologiquement au confort idéal préféré. Cependant l'importance des gradients verticaux et horizontaux est à considérer ainsi que le contexte situationnel défini par les autres paramètres d'influence (environnement : température d'air, vitesse d'air, hygrométrie ; être humain : activité, habillement). L'habitabilité effective du volume dans sa totalité en dépend. La température moyenne de rayonnement est un paramètre premier pour l'appréciation d'une ambiance radiative. Elle peut être obtenue par la méthode des radiosités pour ce qui concerne les émissions des parois grises. Pour les sources ponctuelles ou pour le rayonnement solaire, une méthode numérique du type « Monte Carlo » permet d'en approcher la valeur. La gestion thermique optimale d'un volume doit prendre en compte l'influence des rayonnements internes. Le coefficient $B$ est un indicateur qui suit cet objectif. Le contrôle des ambiances radiatives implique un dimensionnement convenable des vitrages ainsi que l'installation d'éléments appropriés (voilages, stores à chaleur latente...). Des exemples d'études théoriques et d'expérimentations montrent les effets positifs et néfastes des rayonnements pour une conception adaptée des volumes.
\end{abstract}

\begin{abstract}
The concept of dwelling is connected with the thermal comfort problem. Radiatively out of balance volumes may agree physiologically and psychologically with the ideal preferred comfort. Nevertheless taking into account vertical and horizontal gradients is a necessity, as well as other parameters of influence like air temperature, air velocity, hygrometry, activity and clothing. The mean radiant temperature is here determined by the radiosity method for grey surfaces combined with a Monte Carlo method for solar or punctual sources. The search for optimal thermal management must account for ambient radiation. The $B$ coefficient aims at this goal. Ambient radiative control is related to a correct sizing of the glazings and needs the use of complementary elements : shutters, shadings, air fans... A few experimentations demonstrate the positive effects of radiation in a convenient concept of volumes.
\end{abstract}

\section{Introduction.}

The more recent trends for housing projects are essentially based on criteria of energy savings. They combine insulation, solar gains and inertia, but the problem of comfortable environment is often overlooked. In France, the $G$ [1] and $B$ [2] coefficients which officially characterize the thermal qualities of the buildings only take into account the energy saving aspect.

In the older buildings, with smaller windows, the air temperature was close to the dry bulb resultant temperature. This parameter could then be used as a comfort reference. Even in these cases, uneven distributions of temperatures could be met. For example in winter, due to inadequate insulation, the peripheral walls used to be colder than the indoor air, and the presence of fire-places, stoves and radiators resulted in warmer or colder local temperatures. As a result, the space, actually lived in, was reduced since the thermal gradients were variously appreciated.

Research for an optimal insertion of modern dwellings in a climatic context, with a view to energy saving lead us to an entirely different conception of volumes. Air temperature may not any longer be kept as a comfort index. The criteria of thermal comfort for the human body are the only ones through which the concept of habitability may be expressed.

These criteria are of two types :

- psychological ones related to the living nature of man. Such criteria are only determined by experiments, tests and inquiries. The pleasant impressions and sensations experienced vary with the thermal conditions, the personal aspects of affectivity, way of life, decoration, age, sex...

- physiological ones due to the complex physical constitution of man. The various processes of ther- 
mal exchange are correlated as far as the human machine is concerned to null balance conditions.

The study of these two closely linked aspects leads to the setting up of diagrams defining comfort situations for man.

In order to determine the irregular distribution of radiation inside a given volume, numerical techniques are required. The Monte Carlo method, for example, provides visual and mathematical information about the mean radiant temperature at any point of a given volume.

The control of ambient radiation can be achieved in two different ways :

- by modulation, interception or diffusion systems : curtains, blinds, shutters, etc.

- by compensation interfering on the other comfort parameters : air temperature and velocity for the environment, clothing for the human body, radiative complementary sources...

The purpose of this text is to study the various aspects of radiative environments and comfort, to point out the importance of the subject and to report about a few systems that have already been experimented.

\section{Thermal comfort of the human body.}

2.1 THE THERMAL BALANCE. - Homeothermy involves the thermal neutrality of a man in respect to his environment. This may be expressed by equation (1) :

$$
S=0
$$

where $S$ is the balance of energetic exchanges. $S$ includes 3 groups of terms :

- Metabolism which only depends on man.

- Conductive and convective exchanges, through respiration and skin.

- Radiative exchanges between the effectively radiative surface and the environment. The precise form of each expression has been previously presented [3].

Resolution of equation (1) supplies a set of values for the 6 parameters (air temperature $T_{\text {air }}$, mean radiant temperature $T_{\mathrm{mr}}$, air velocity $V_{\text {air }}$, air relative humidity $H_{\mathrm{r}}$, metabolic activity Act, clothing insulation $R_{\text {clo }}$ in clo unit $\left.\left(1 \mathrm{clo}=0.155 \mathrm{~m}^{2}{ }^{\circ} \mathrm{C} \mathrm{W}^{-1}\right)\right)$ making up comfort sheets in a 6 dimensional space. In the zone related to temperate climates, the influence of hygrometry is weak. The view in $\left(T_{\mathrm{a}} ; T_{\mathrm{mr}}\right)$ plan, with $V_{\text {air }}, R_{\mathrm{clo}}$, Act and $H_{\mathrm{r}}$ as parameters is the one which points out, the best, the influence of radiative environments on comfort.

In the optimal comfort zone, the comfort lines are entangled. The effect of one parameter may easily compensate the effect of another one. This zone is centered in radiatively out-of-balance situations. The ideal situation is $\left(T_{\text {air }}=16{ }^{\circ} \mathrm{C}, T_{\mathrm{mr}}=27^{\circ}\right)$ (Fig. 1). Man is fitted to live in radiative environments, a fact which proves also true from a psycholo-

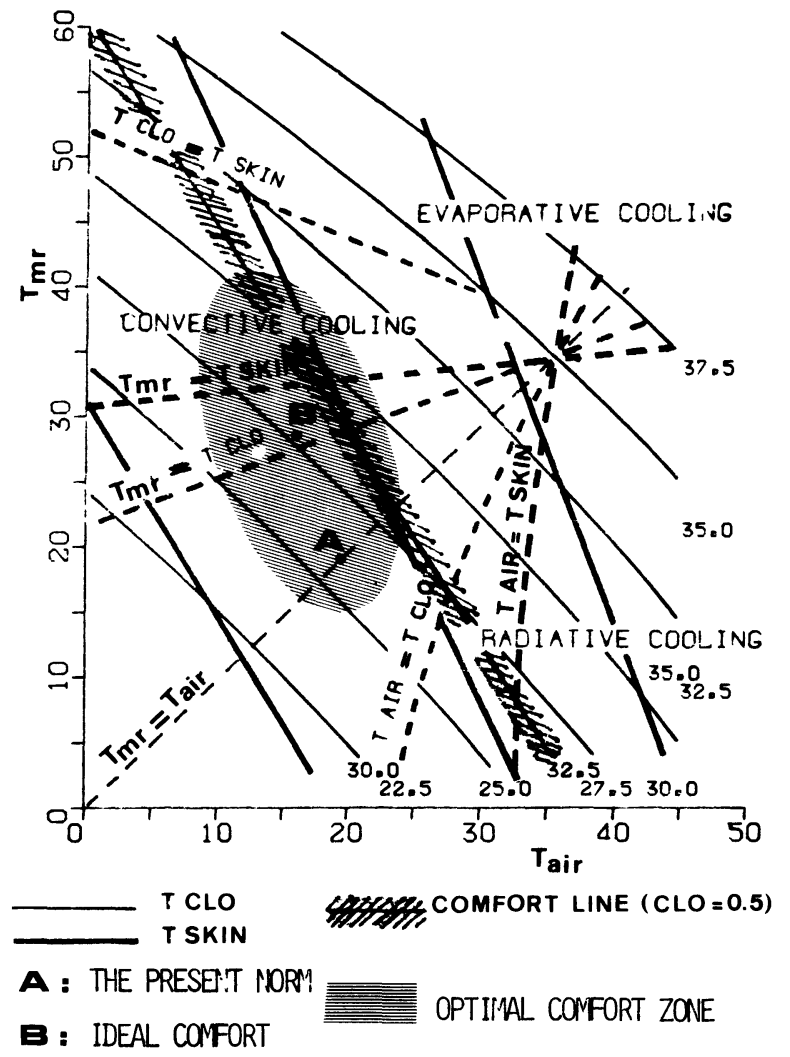

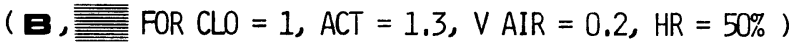

Fig. 1. - The comfort zones.

gical point of view. Whether it be the present return to nature, sun-flooded beaches, ski-ing resorts, open fires or habitable greenhouses, they all plead in favour of radiative environments. Radiation implies the existence of gradients which avoid saturation of the organs of perception [4]. As a result, radiation, together with cool air, pleasant to breathe, are felt to be stimulating and enjoyable.

Figure 2 confirms the pleasantness offered by radiative environments.

The radiative situations suitable for dwellings are linked to a cloth emissivity indifference $\left(T_{\mathrm{mr}}=T_{\text {clo }}\right)$. This interesting feature is unconsciously used : the color and types of clothing surfaces vary widely under temperate climates.

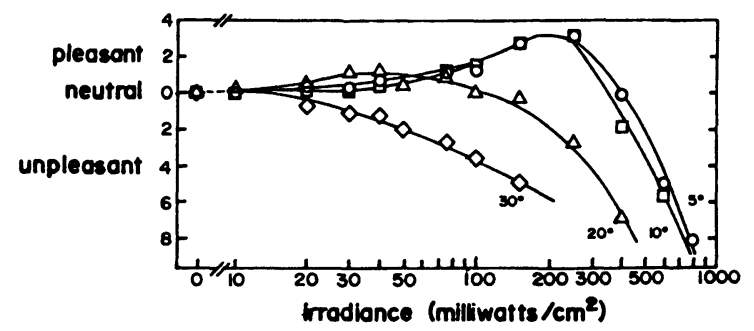

Fig. 2. - Average magnitude estimates of pleasantness and unpleasantness as functions of stimulus irradiance. The parameter is air temperature. Each point is the average of two or three judgments per session made during two or three [5]. 
The optimal comfort zone is upper bounded by the node :

$$
T_{\mathrm{clo}}=T_{\mathrm{sk}}=\frac{h_{\mathrm{r}} T_{\mathrm{mr}}+h_{\mathrm{c}} T_{\mathrm{air}}}{h_{\mathrm{r}}+h_{\mathrm{c}}}=T_{\text {operative }}
$$

where $h_{\mathrm{r}}, h_{\mathrm{c}}$ are the linear heat transfer coefficients for radiation and convection.

The operative temperature appears in the literature in many forms: Température résultante of Missenard, Equivalent temperature... It is an average of $T_{\mathrm{mr}}$ and $T_{\text {air }}$ weighted by the linear radiative and convective heat transfer coefficients observed at the body exterior surface [6]. It is a direct measure of the environmental heat stress on a human subject due to sensible heat exchange alone.

The line corresponding to the equation is :

$$
T_{\mathrm{mr}}=\frac{-h_{\mathrm{c}}}{h_{\mathrm{r}}} T_{\mathrm{air}}+\frac{h_{\mathrm{r}}+h_{\mathrm{c}}}{h_{\mathrm{r}}} T_{\mathrm{sk}}
$$

The situations correlated with this node are met in the ski-ing stations at Easter period: the sunlight radiation, direct, diffuse and reflected by snow is opposed to a cold air. An indifference to cloth is observed, in accordance with the fact that clothes insulate two zones at the same temperature.

The optimal comfort zone is lower bounded by the node $T_{\text {air }}=T_{\text {sk }}$.

The situation correlated with this node is the sleep « à la belle étoile » in hot countries. The air movements are felt with indifference, in accordance with the null convective exchanges.

Above and below these nodes the comfort is unstable [3] ; the comfort lines diverge : any deviation from a comfort situation due to a variation of a parameter can't be compensated by the natural effect of another. For instance, in the case of a hot air, increasing the activity corresponds to increasing the metabolism, and also be increasing the convective gains. Five particular lines pass through the optimal comfort zone (i.e. through the radiative comfortable zone); they are :

a) $T_{\mathrm{mr}}=$ Constant

b) $T_{\mathrm{mr}}=T_{\mathrm{sk}}$

c) $T_{\mathrm{mr}}=T_{\mathrm{clo}}=\frac{0.155 h_{\mathrm{c}} R_{\mathrm{clo}}}{1+0.155 h_{\mathrm{c}} R_{\mathrm{clo}}} T_{\mathrm{air}}+$

$$
+\frac{1}{1+0.155 h_{\mathrm{c}} R_{\mathrm{clo}}} T_{\mathrm{sk}}
$$

indifference to cloth emissivity.

d) $T_{\text {air }}=T_{\mathrm{mr}}$

e) $T_{\text {air }}=T_{\text {clo }}$

$$
T_{\mathrm{mr}}=\frac{1+0.155 h_{\mathrm{r}} R_{\mathrm{clo}}}{0.155 h_{\mathrm{r}} R_{\mathrm{clo}}}-\frac{1}{0.155 h_{\mathrm{r}} R_{\mathrm{clo}}} T_{\mathrm{sk}}
$$

indifference to $V_{\text {air }}$.
Remarks :

a) The radiative situations suitable for dwellings are shown to be in the zone delimited by the two lines $T_{\mathrm{mr}}=T_{\text {clo }}$ and $T_{\mathrm{mr}}=T_{\mathrm{sk}}$. So, in this zone, $T_{\mathrm{mr}}$ is the temperature of the cloth at a depth varying between the skin and the external surface.

b) $T_{\text {sk }}$ is correlated to the activity and $T_{\text {clo }}$ to the cloth insulation. Therefore in the optimal zone were $T_{\mathrm{mr}}$ is nearly constant, and consequently almost independant of $T_{\text {air }}$, the compensation between each parameter effect is maximum (Fig. 3).

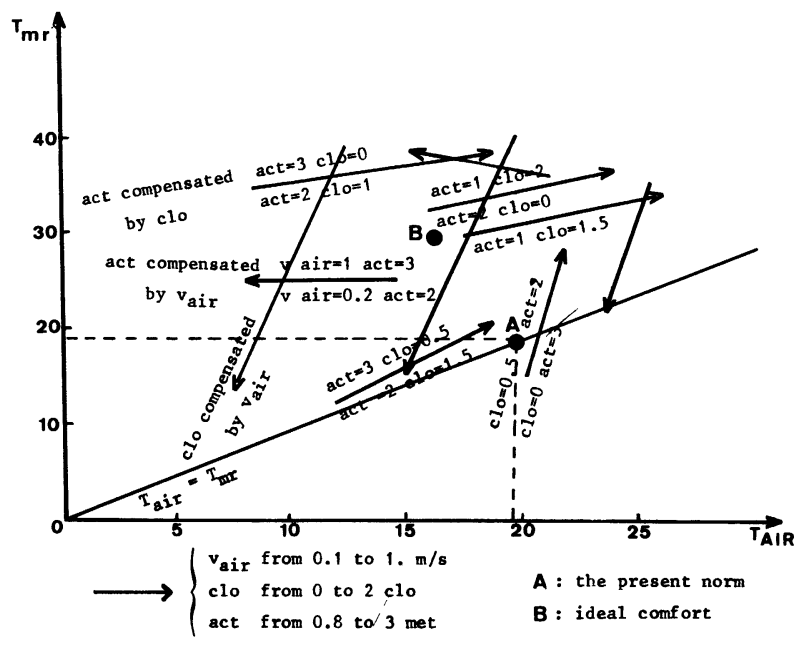

Fig. 3. - Some aspects of compensation activity-clothingair velocity.

c) The minor axis of the elliptic optimal zone corresponds to the relation :

$$
T_{\mathrm{mr}} \cong \frac{T_{\mathrm{clo}}+T_{\mathrm{sk}}}{2}
$$

2.2 RADIATIVE ASYMMETRIES. - The mean radiant temperature $T_{\mathrm{mr}}$ is the first useful parameter for the evaluation of the radiative ambient aspect. Owing to the insulating function of clothes and to blood circulation which keeps a global balance of the various parts of the body according to energetic gains or losses, owing to the ability for indifferent (imperceptible) or unconscious adaptation, directional characteristics do not appear as, essential.

Nevertheless two reasons require that they should be taken into account :

- The contact of the feet with the ground involves sensitiveness to ground temperature gradients $\left(6{ }^{\circ} \mathrm{C}\right.$ of amplitude with respect to a comfortable environmental temperature, or $4^{\circ} \mathrm{C}$ per minute are the maximal permissible geometrical or temporal gradients) and to high or low ground-temperature (26 ${ }^{\circ} \mathrm{C}$ maximum) [7]. The shoes action is to remove these limits. 
- On the one hand, blood circulation is twice as fast in the head and shoulders as inside the rest of the body ; on the other hand both head and shoulders taken together afford the smallest surface area of exchange considering the volume concerned (spherical shape). The result is that this part of the body is particularly sensitive to vertical gradients.

At each point $\mathrm{P}$, a radiation vector is a vector whose projection upon any direction is numerically equal to the difference in irradiance between the two sides of a plane element placed at $\mathrm{P}$ and normal to that direction [7]. The last experiments show $10^{\circ} \mathrm{C}$ to $12{ }^{\circ} \mathrm{C}[8]$ to be the limit of the vertical radiation vector permissible without discomfort. In case of a cold ceiling, this vector limit is reduced by 2 degrees.

The horizontal radiation vector may be quite large [9-10]: $8{ }^{\circ} \mathrm{C}$ less, near a cold panel, with respect to comfortable ambience do not produce any feeling of discomfort, which shows a wide tolerance to high gradients as long as man remains in a situation of comfort (up to $16^{\circ} \mathrm{C}-18^{\circ} \mathrm{C}$ ). These results lead us to give the following advice :

- search for comfortable radiation situations

- take advantage of solar radiation only when horizontal (the whole daytime in winter, mornings and evenings in the half-season). But care must be taken against dazzling. Glazed roofs should only be used in countries enjoying a diffuse radiative sky

- use ground heating at low temperature, small gradients both in time and space ; interest should be pointed out for phase change materials

- use powerful heaters fitted with radiative systems and horizontal fluxes (vertical panels of fireplaces).

\section{The Ecorad code and the determination of mean radiant temperatures.}

Since mean radiant temperature can vary with position in a volume and from time to time, it is necessary to determine its value.

The numerical method for the study of radiative environments provides, at any moment, information about the exchange fluxes between surfaces, sources and receptors as well as about the radiant and comfort temperatures at any point inside a given volume [11]. It includes two parts :

processing of the information concerning the surfaces as greybody with a lambertian emission

processing of the data for peculiar sources (sun, radiators or cold sources).

We consider first rectangular surfaces, either parallel or perpendicular to one another. Each of them has a constant mean emissivity in the infrared band and a constant temperature $T_{i}$. Leaving-flux densities (radiosities) $D_{i}$ of the surfaces are obtained by iteration :

$$
D_{i}=\varepsilon_{i} \sigma T_{i}^{4}+\left(1-\varepsilon_{i}\right) \sum_{J \neq i} F_{i J} D_{J}
$$

where $\sigma$ is the Stefan-Boltzmann constant $\left(\sigma=5.6710^{-8} \mathrm{Wm}^{2} \mathrm{~K}^{-4}\right)$ where $F_{i J}$ is the form factor between the surfaces. Radiant temperature $T_{\mathrm{r}}$ at a point $\mathrm{P}$, due to the influence of the surfaces only is connected to the radiosities by the solid angles $A$ under which these surfaces can be seen from $\mathrm{P}$ :

$$
T_{\mathrm{r}}^{4}(\mathrm{P})=\frac{1}{\sigma} \sum_{i} A(\mathrm{P}, i) D_{i} .
$$

As concerns the sun's influence, the Monte Carlo method simulated the phenomenon through statistical sampling, which, provides an accurate description. The principle consists on following the trajectory of random sun rays selected with their statistical distribution. Interactions are also selected, at random, according to the statistical absorption-diffusion-reflection distribution. Selection of the non specular direction is likewise random within the statistical repartition of the diffusion lobe of the surface.

Taking account of the local site, the orientation of the surface (or the window), the insolation fraction, the time of the year, the glazing transmission, the solar flux entering the room is calculated for the chosen time. It is then subdivided into a number $N$ (generally 2000 ) of beams having the same energy. The accurate trajectory of each of them is studied.

A generator of pseudo-random numbers performs selections of $G$ numbers according to a normal law. The distribution diffuse radiation/global radiation, the direction of the diffuse beam, the beam geometrical coordinates, absorption or reflection (specular or diffuse) on a surface... refer to as many laws of probability.

The complete trajectory of each beam is followed and counters are incremented for each elementary cubes ( 0.3 to $0.5 \mathrm{~m}$ side) crossed through in the room.

The counter of each cube is incremented once at most during the whole optical trajectory of the crossing beam. The incident solar in any basic volume of the room as well as the energy absorbed by each surface element of the sides can be thus computed which enables us in turn to deduce the radiative temperature.

The same procedure applies for a hot punctual source inside the room, but with an isotropic or nonisotropic emission in a solid angle given a priori ; for instance, in the case of an isotropic emission in a $4 \pi$ angle, the $\phi$ and $\theta$ emission directions (azimuth and zenith angles) are associated to the $X$ and $X^{\prime}$ random selections by the following relations :

with

$$
\begin{aligned}
\phi & =2 \pi X \\
\sin \theta & =2 X^{\prime}-1 \\
0 & <X, X^{\prime}<1 .
\end{aligned}
$$

A cold source is a source which traps more energy than it produces. It may be considered as a hot source, but with a negative energy : its emission is assumed to be punctual but its absorption. must necessarily be volumetrical.

Figure 4 shows a visualization example of the radiation inside a sunlit room. All the reflections here are specular. 


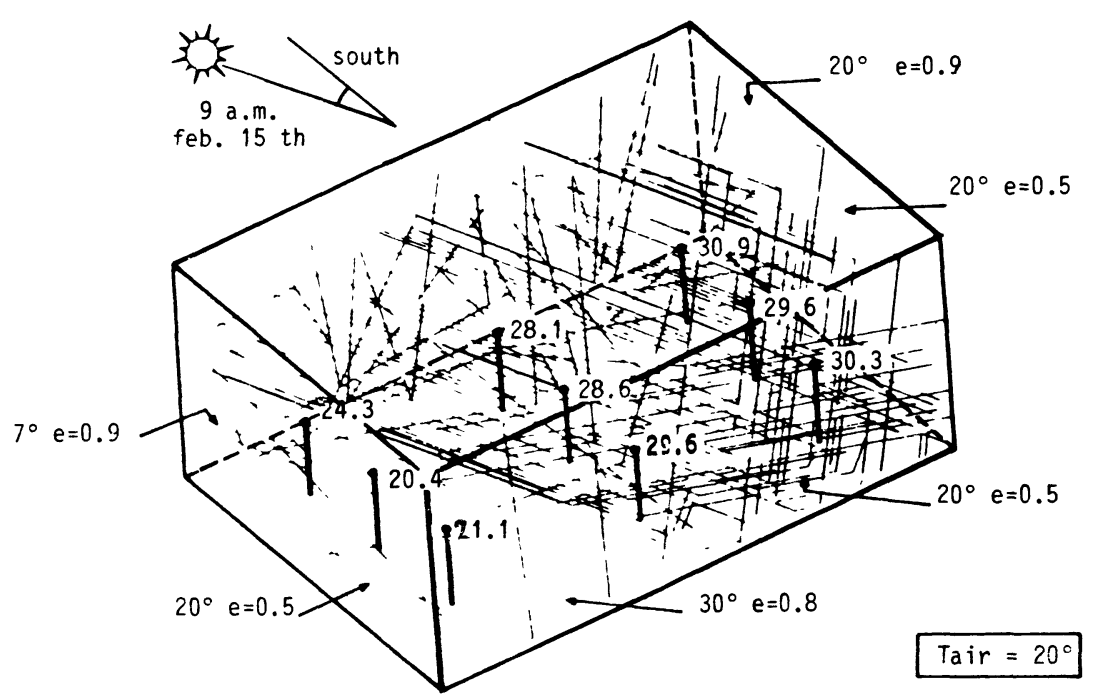

AN APPLICATION OF ECOPAE CORE : SPATIAL DIAGRAM OF THE COMFORT TEMPERATURE IN A ROOM; 150 RAYS ARE ORESENTED WUNG 4000 COAPUTED;

Fig. 4. - Radiation inside a sunlit room.

As it is the case with all statistical methods care must be taken when counting the elementary beams. As a matter of fact the crossing of the cubes by adjacent sides produces an error which can be fairly well corrected by introducing the following factor:

$$
X=\frac{N}{\sum N_{i J k}}
$$

where $N_{i J k}$ is the number of rays crossing the $i J k$ cube, the summation being extended to the cubes surrounding the emission source (window).

\section{Radiation management.}

The knowledge of the mean radiant temperature and of directional constraints imposed for comfort lead to several procedures of radiation management : mes,

- preventive actions in the conceptions of volu-

- actions limiting the radiative effects,

- compensations for the radiative effects.

4.1 GLOBAL CONCEPTION OF VOLUMES : $B$ AND $G$ : EXAMPLE OF THE TOURRETTES SOLAR HOUSE. The $G$ coefficient of a lodging is defined as the thermal volumetric losses for one degree temperature difference between indoor and outdoor air, per cubic meter of living volume [1].

It is computed by addition of thermal losses of elementary areas $d_{\mathrm{s}}$ or lines $d_{\mathrm{e}}$ and of thermal losses due to air renewal $d_{\mathrm{a}}$.

The general formula is :

$$
G=\frac{\sum d_{\mathrm{s}}+\sum d_{\mathrm{e}}+d_{\mathrm{a}}}{V} .
$$

The $B$ coefficient has been introduced to take advantage of the free gains [2] :

$$
B=G(1-F)
$$

where $F$ is a coefficient of free gains which mainly refers to internal gains and solar radiative gains.

Search for a good $B$ coefficient must not lead to forget the necessary comfort aspects attached to a lodging: the radiative solar gains for clear days happen mainly around midday. Then the solar gains should widespread along the daytime by widely oriented windows and large thermal inertia. A low $B$ coefficient never supersedes a bad $G$ value by the fact that, at some times, $G$ is the only coefficient which has to be considered.

The architectural aspects linked to these considerations have been taken into account : as shown for the Tourrettes house.

In a clear day of January, a south-east or southwest window catches 80 per cent of the solar energy got by a south one. Moreover these two orientations are perpendicular. Several rooms were concepted in order to take advantage of this peculiarity and to offer a large overview on the beautiful landscape. Protections against summer sunlit was also insured. A small solar greenhouse ( $8 \mathrm{~m}^{2}$ of glasses), with a P.C.M. storage inside, was associated to disphase a part of the solar radiative gains which should have lead to overheating and overlighting the livable space. The drawing of this house was done by the architect $\mathrm{Ch}$. Petitcollot with the help of an Heliodon to respect these considerations and to satisfy the most possible " the games of light and shadow » as suggested by Le Corbusier and which are so pleasant for man.

Figure 5 shows this house. 


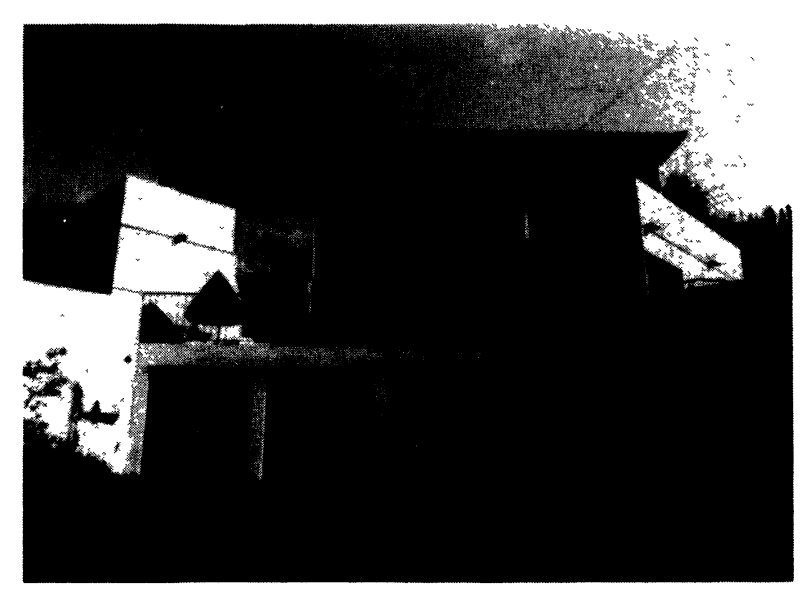

Fig. 5. - The Tourrettes solar house.

Other considerations more mathematical have also been made, related to comfort and economical aspects.

While, according to administrative rules, $G$ and $B$ should be 0.95 and $0.65 \mathrm{~W} / \mathrm{m}^{3}{ }^{\circ} \mathrm{C}$, the values corresponding to this house are 1.16 and 0.58 . The large bay-windows $(58 \%$ of the total losses for a $13 \%$ surface facing outside) account for such a poor $G$ associated to such a good $B$. This value of $B$ as compared to the prescribed one accounts for an annual economy of $1277 \mathrm{kWh}$. It also accounts for a non-heating temperature of $14.7^{\circ} \mathrm{C}$. As the $B / G$ ratio is 0.5 as opposed to the 0.32 ratio of prescribed values, the result is that half the needs are directly or indirectly provided for by solar gains, i.e. about 12 hours heating per day is, thus, insured. Inertia spreads out the surplus gains. If we take cloudy days into account (1 day out of 2 in Nice) and the mean duration of sunshine in winter, we can see that the limit for habitability is reached : the thermal climatic cycle is well centered on the ideal comfort situation (Fig. 6). As a matter of fact, such a result implies over lighted zones on the middle of a sunny day ; their comfort effect, however, is partially limited by the presence of extensive, cold glazing. This is why the search for a minimal $B$ is not a good comfort aim since it corresponds to a succession of volumes that are in turn radiatively over-heated or too cold. The value adopted for $B$, for Tourrettes house, stands as a realistic optimal value, as the next paragraph shows.

4.2 The ClimATIC CYCLES. - The heating strategy can be set out when looking at the climatic cycle of the outdoor mean radiant and air temperatures during a winter day. Such a cycle corresponds to an ellipse of which the major axis is almost perpendicular to the major axis of the optimal comfort zone (Fig. 6). The strategy consists in modifying this cycle to improve indoor mean cycle. This may be obtained by several methods:

- by cutting or translating the bottom part of the ellipse by a complementary heating, partial or total upward translation of the climatic cycle, additional

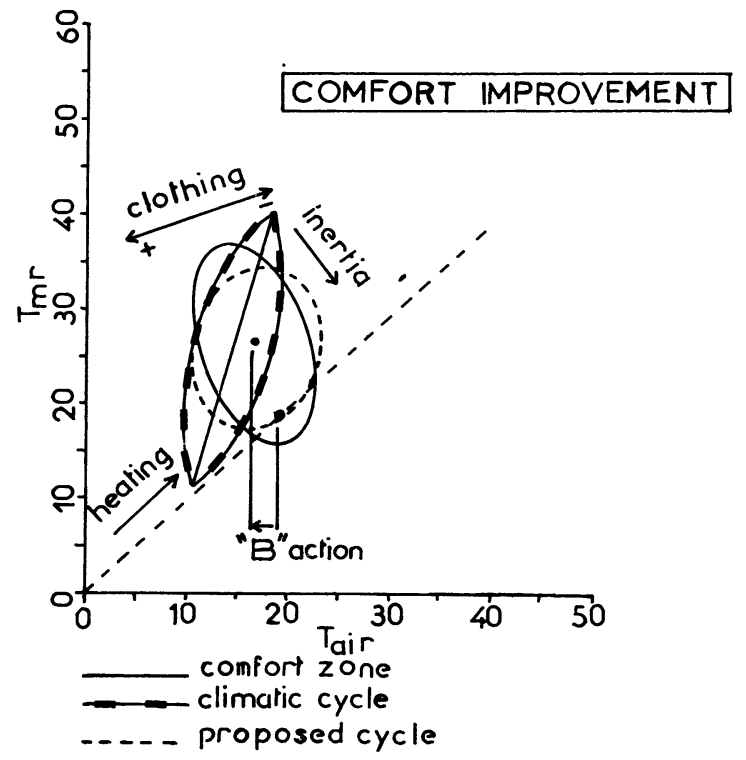

Fig. 6. - The climatic cycles.

clothing (downward translation of the optimal zone in the middle of winter and also during sleep) ;

- at midday, by cutting the upper part of the climatic ellipse by setting up protection against solar radiation as long as possible with storage systems, or by translating the optimal comfort zone to the upper part by reducing activity and clothing ;

- by increasing the minor axis of the climatic cycle, maintaining the air and radiant temperatures near their maximum values (inertia giving back the midday surplus energy in the evening) ;

- by keeping the center of the indoor cycle near a comfort line, and within the outdoor climatic cycle. This translation from the line $T_{\mathrm{air}}=T_{\mathrm{mr}}$ towards higher $T_{\mathrm{mr}}$ values is the action of $B$. Its amplitude varies with the size of the indoor cycle that may be obtained (importance of inertia, importance of varying activity and clothing).

All this corresponds to an optimal insertion of the lodging in the climatic context and a way of life in relation with the climate (Fig. 6).

In the case of the Tourrettes solar house, the $B$ value is related to a non-heating temperature of $14^{\circ} 7$, and $B / G=0.5$ corresponds to a division of the climatic cycle into two equal parts. This result confirms that the adopted value on $B$ is optimal.

This analysis of heating problems in relation with comfort constraints leads to a few conclusions :

- the $\left(19^{\circ}\right)$ norm is only a comfortable situation found at times but which should not be used as a reference target. An economic strategy must consider radiative environments as better than homogeneous ones ;

- air velocity and radiative temperature, as well as clothing and activity, are parameters that may correct unsuitable temperature. These two first parameters must be adopted in an optimal command of heating systems. 
4.3 FIXED ELEMENTS OF RADIATION CONTROL. There is no need to recall the advantages provided by penthouses-caps to avoid the incidence of the direct midday radiation. The double South-EastSouth-West orientation of the Tourrettes house has been adopted to favour the solar radiation incidences in the morning and evening as well as to limit the midday ones. In addition to screens determined by geometrical conditions of direct solar radiation interception, selectivity and transmittivity of glazing affords a way of acting on the indoor environment. In winter, direct solar radiation enters far and deep into the rooms. A moderate absorptivity prevents the glazings from being cold and avoids condensation. Thus, a uniform radiative temperature inside the considered volume is obtained. A somewhat cooler air compensates radiation when the weather is sunny.

In summer, direct solar radiation remains close to glazing. The oblique incidence, almost vertical, and high absorptivity result in overheating near the glazings. This is why aesthetics will not be the only criteria, to choose between high transmittivity glazing in association with an outside blind or awning on the one hand, and highly absorbing and reflecting glazing on the other hand. Account must be taken of the climate of the area, the orientation and the size of the bay-window, and the room destination.

Effusivity of the internal walls also helps to control radiation. It allows an inertial smoothing out that prevents solar overheating and improves comfort by a radiative effect. The two following applications are illustrative of this procedure.

\section{The Rectorat of Nice :}

- the study of the climatization of this building has been achieved in association with the TETA Office. The building has been in use since December 1982 [12]. Considering the small number of days where air-conditioning is necessary, and accounting to the fact that during that period most of the staff is on holiday, a natural solution has been adopted.

Figure 7 shows for this building the correlation between minimal and maximal outdoor air temperatures. One time out of two, due to the clearness of the sky, high maximal temperatures are associated with low minimal temperatures. Solar gains are limited by means of reflecting glazing (solar transmittivity is $34 \%$ and $16 \%$ with an outside blind) and by means of insulating window-basements. Double flux night ventilation is used $(2 \mathrm{vol} / \mathrm{h}$ but this may be raised round $4 \mathrm{a} . \mathrm{m}$. if the cooling action happens to be insufficient) to cool down the massive interior walls (ground and ceiling, mainly). Thus, in the daytime, renewal air is cooled down and cold radiation from the walls permits to lower comfort temperature. Figure 7 shows, as a result of the Ecorad code, the histogram of the air and comfort zones in an office depending on the type of glazings used. The efficiency of this process is limited because of the condensation problems on the walls (high air humidity in summer) which needs that the temperature difference between air and walls should never exceed
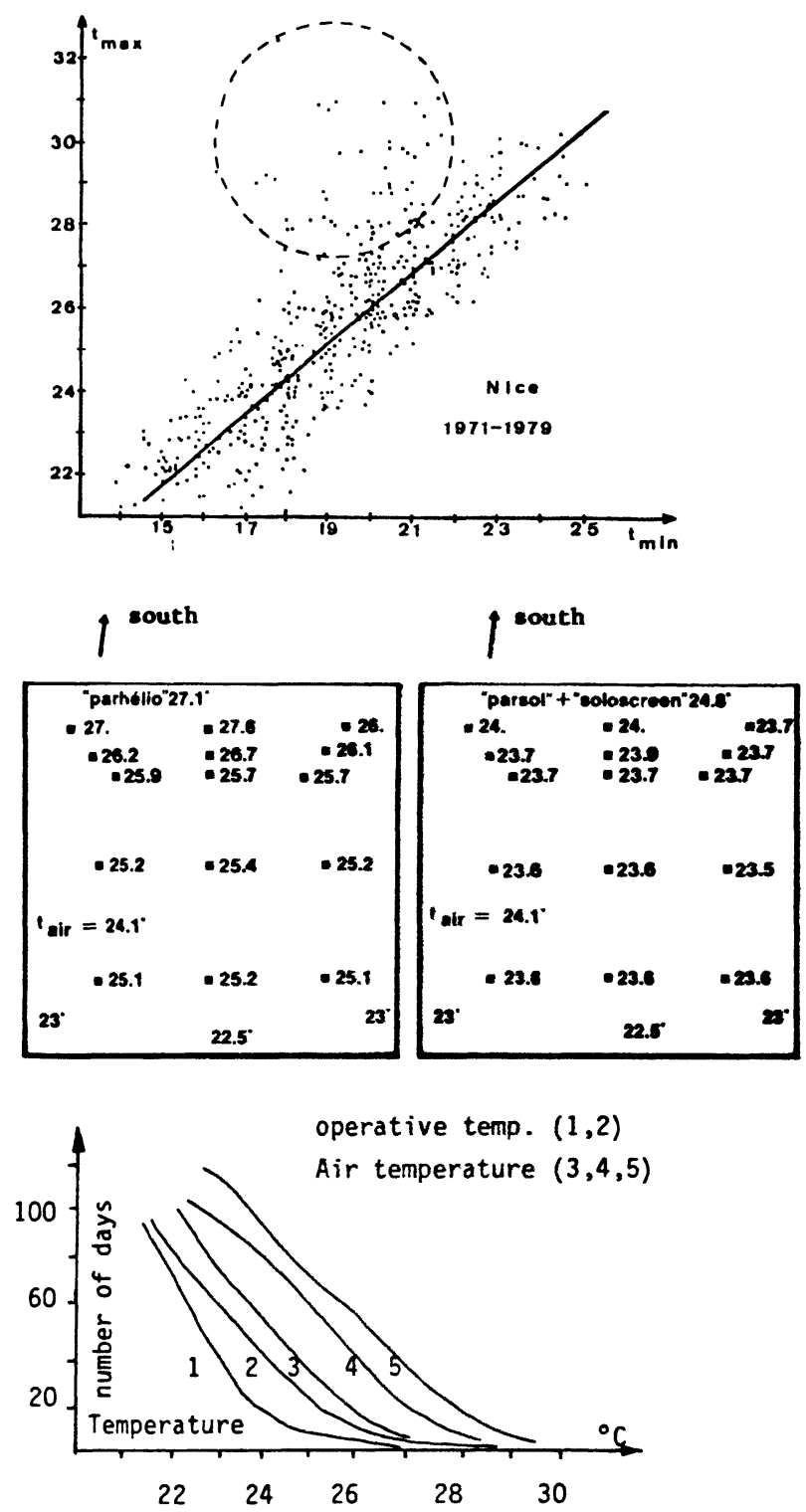

1 : all day ventilation; diurnal climatisation from july to september

2 : all day ventilation

3 : internal air temperature (nocturnal ventilation)

4 : external air temperature

5 : internal air temperature (without nocturnal vent.)

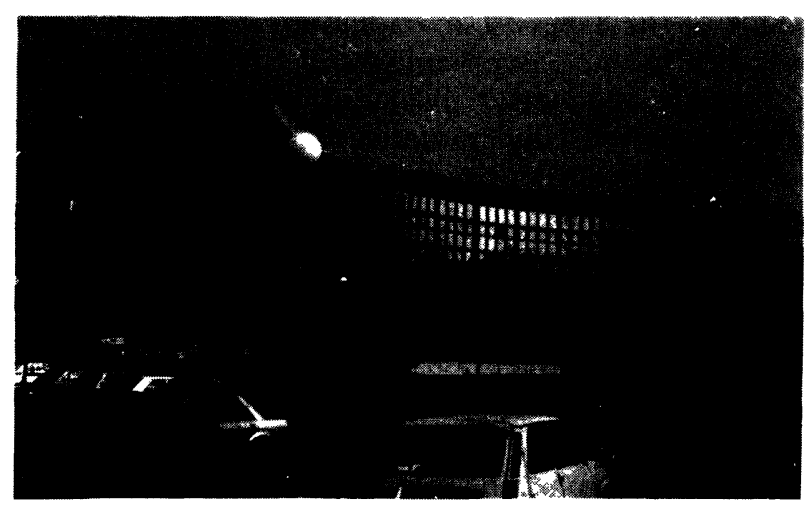

Fig. 7. - Radiation and comfort: the new rectorat building in Nice. A. Datas from the french National Meteorological Institute. B-C. Computed results. D. The Rectorat building. 
$7{ }^{\circ} \mathrm{C}$. Nevertheless, it provides a satisfactory solution to the problem of climatization insofar as it saves the expense of more costly installations.

The Le Tignet solar house :

- The originality of Le Tignet solar house (architect : Ch. Petitcollot) is based on its modern adaptation of a ground heating device already used by the Romans, namely the hypocaust. The hollow gauge bricks of the floor are used as air pipes which, besides using the ground as a thermic buffer, allows to combine ground heating (affording, at low temperature, a fairly uniform distribution of calories) and air-heating since hot air comes out of the pipes through grids places at the base of the glazed baywindows $[13,14]$. Since the form factors between the ground and the bay-windows are small, heating losses to the outside are reduced by $3 \%$ insofar as an equivalent comfort temperature can be obtained with an $1 / 2^{\circ} \mathrm{C}$ cooler air. Moreover the vaulted ceiling creates a focus effect which increases the comfort feeling (feeling of warmth in the room) and helps the convective movements of the air avoiding air stratification.

\subsection{MOBILE ELEMENTS OF RADIATION CONTROL. -} Glazing is a transparent, non-inertial separation surface. As solar radiation varies considerably in intensity and direction, and as the temperatures of the separated zones may be very different, glazing requires additional elements. They fall under three categories :

- elements for interception or insulation (shutters, curtains),

- elements for diffusion (veils, blinds),

- an element for interception, diffusion, insulation, disphased restitution of the intercepted energy : the p.c.m. venitian blind.

The effects of the first series of elements are due to a kind of « hit or miss » action, while the second ones make uniform the radiative environment. As to the third element, it acts at once as a shutter, a solar collector provided with storage and as a radiator. It has been patented and already presented several times [15]. Thanks to its interception and storage of a part of the excess solar radiation, it prevents from over-heating and over-sunlighting. Thermal storage restitution and better insulation provide additional calories, essentially radiative $(55 \%)$ and ensure partial and well distributed space heating. Figure 8 shows the reduction of the thermal ellipsoid cycle due to this element.

4.5 AIR/RADIATION COMPLEMENTARITY. - Under temperate climates, various types of action are considered to compensate the influence of radiation on comfort :

- those on clothing and activity. They depend on man only. They can be favoured but can not be established once for all ;

- the actions on air velocity and air temperature (the actions on hygrometry are very limited).
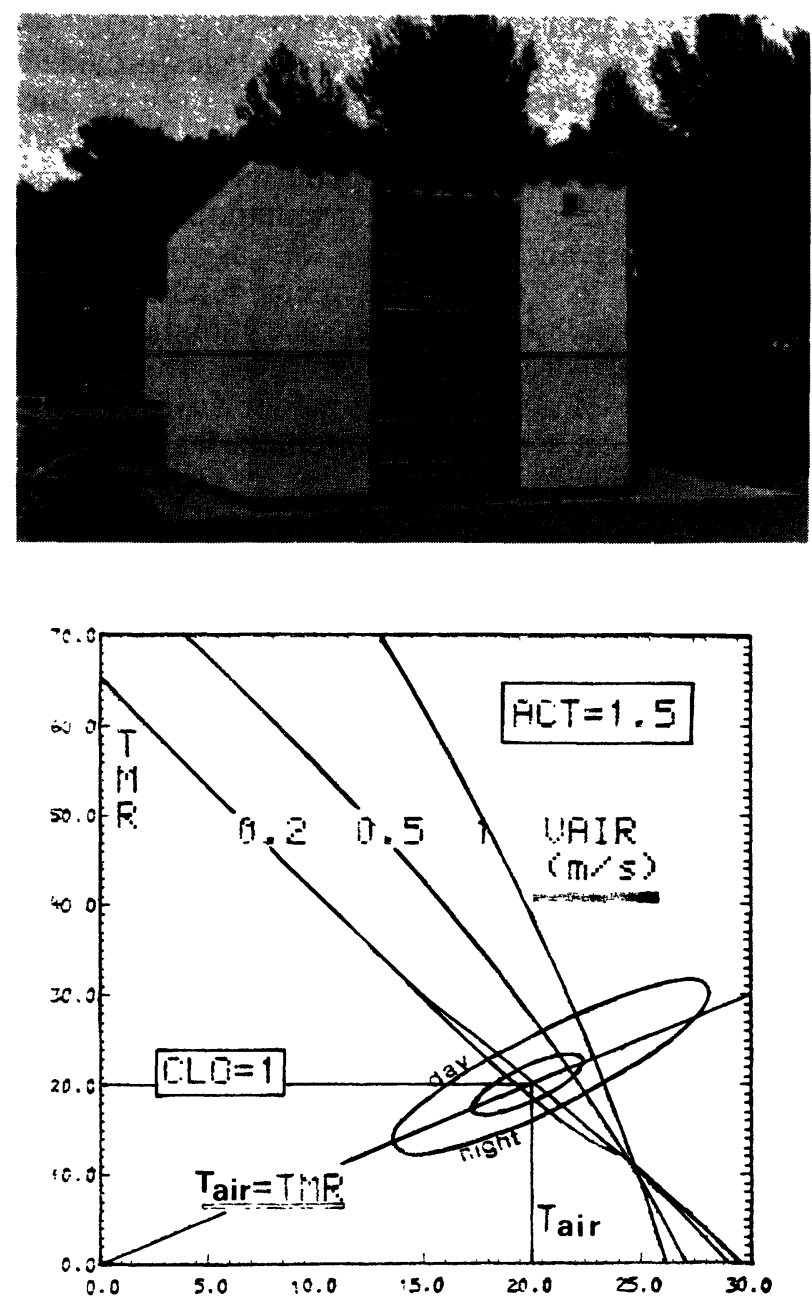

Fig. 8. - Our experimental cell and the comfort cycles as observed with it. Comparison between the pcm venitian blind (internal cycle) and an ordinary blind (external cycle).

Temperature modulation is a slow process whereas change of air velocity can be obtained almost immediately. This is why, in volumes exposed to variable sunlight (cloudy spells), ventilation should be chosen as the active parameter. In areas enjoying constant sunlight (Normandy, South-Eastern France) air temperature may be the compensating parameter ;

- the actions on radiation by use of IR radiators.

The Opio solar house :

This house has been the support of an experiment about comfort :

During clear winter days the dining-room undergoes three different states of comfort. The results have been plotted in figure 9 and are confirmed by the feelings of comfort experienced :

In the morning, the walls and air of the room which have not been heated during the night are at about $15^{\circ} \mathrm{C}$. But as the window is oriented $60^{\circ}$ South-East, sunlight enters far and deep into the rooms and increases the comfort temperature up to 


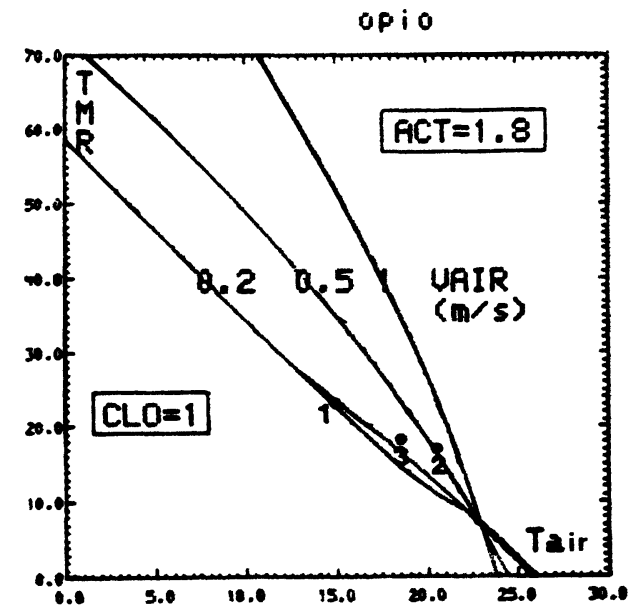

Fig. 9. - Comfort observed situations in Opio solar house : 1) morning ; 2) afternoon ; 3) evening.

$23{ }^{\circ} \mathrm{C}$, in the sunlit zones. The inside air is motionless and for an average 1.8 met activity, comfort feeling is obtained.

In the daytime, the hot air produced by the solar collecting roof is driven into the high ceilinged room $(4.5 \mathrm{~m})$. At $1.5 \mathrm{~m}$, in February-March air is at about $21^{\circ} \mathrm{C}$ when the weather is fine, but the walls are still cold and the sun no longer enters the room directly, which lowers the radiative temperature to about $17.5^{\circ} \mathrm{C}$. On the other hand, air velocity is of $0.4 \mathrm{~m} / \mathrm{s}$. The warmth of the air is experienced as pleasant because its velocity prevents the heavy sensation given by hot motionless air.

The solar collector stops at the end of the afternoon and air becomes motionless again. But as the walls have been heated, the comfort situation corresponds to a balance of $18^{\circ}-19^{\circ} \mathrm{C}$ between air and radiative temperatures.

\section{Conclusion.}

Overglazing is an attractive technique for the design of solar houses. However, habitability, which is the aim to reach [16], prevents the designer from turning houses into solar collectors only. Man is a complex machine which enables him to find his balance in various environments. The radiation function is a fundamental one. Its control or compensation provide means of action that are, by no means, new. Cloisters, patios, fountains, mosaic flooring and walling are the evidence of the radiative techniques used in the past and presented in simple and aesthetic forms.

Among the comfort environments, the radiative ones are those which give psychologically to man best agreement : existence of space-time gradients to avoid the saturation of percepting organs $[17,18]$, visual (poor or rich, intense or weak lights...) or respiratory (radiation permits a colder air which satisfies breathing passages better), pleasure experienced which may be different from the one predicted by comfort, but which may be more valued [19].

\section{Acknowledgments.}

The author acknowledges his thanks to $\mathrm{Mr}$ M. Schneider (C.N.R.S.), J.-C. Deval (C.N.R.S.) and $\mathrm{Ch}$. Petitcollot (Architect) for their collaboration in this work.

\section{References}

[1] C.S.T.B. RÈGLES, Th., G 77 (D.T.U.-1977-up to date 1982).

[2] C.S.T.B. RĖGLES, Th., B 85 (Book 2001-1985).

[3] Deval, J.-C., Le confort thermique en climat tempéré, Revue Phys. Appl. 19 (1984) 513.

[4] CABANAC, M., Les signaux physiologiques du confort thermique, Inserm 75 (1977) 27-38.

[5] MARKS, L. E., GonZALEZ, R. R., Skin temperature modifies the pleasantness of thermal stimuli, Nature 247 (1974) 473-475.

[6] GAGge, A. P., Rational temperature indices of thermal comfort (K. Cena and J. A. Clark). Bioengineering thermal physiology and comfort (Elsevier Amsterdam) 1981.

[7] MC INTYRE, D. A., Indoor climate (Applied Science Publishers, Londres) 1980.

[8] Fanger, P. O., Banhidi, L., Olesen, B. W. and LANGKILDE, G., Discomfort caused by overhead radiation (7th Intern. Congress of Heating and air conditioning Clima 2000, Budapest 1980).

[9] ANQuez, J. and CROISET, M., Thermal comfort requirements adjacent to cold walls, application to glazed opening, C.S.T.B. Cahier 96 (1972) 833 .
[10] Olesen, S., FAnger, P. O., JEnSEn, P. B. and NEILSON, O. J., Comfort limits for men exposed to asymmetric thermal radiation, CIB W 45 Symposium: thermal comfort and moderate heat stress, Building research station HMSO, 1972.

[11] Audoin, P., Berger, X., Pause, P. and SchneiDER, M., Etude d'ambiances de rayonnement, C.S.T.B. Cahiers 218 (1981).

[12] Berger, X. and Deslandes, J., La climatisation estivale, Cahiers Tech. Bât., Publ. Moniteur $\mathrm{N}^{\circ}$ 28, (1980).

[13] Petitcollot, Ch. and Groupe d'Ecothermique, A mediterranean latent heat solar house in « Le Tignet », PLEA Conference, Crète, 1983.

[14] Petitcollot, Ch., Maison solaire en climat méditerranéen : stockage à chaleur latente (Conférence internationale sur l'architecture solaire, Cannes) 1982.

[15] Berger, X., Pelletret, R., Deval, J.-C. and Société Griesser, Le store vénitien à chaleur latente (Conférence internationale sur l'architecture solaire, Cannes) 1982. 
[16] Deval, J.-C., Berger, X. and Schneider, M., Comfort aspects in overglazed environments (First conference on solar heating, Amsterdam, Mai) 1984.

[17] Heschong, L., Architecture et volupté thermique, Editions Parenthèses, 1981 et Thermal delight in architecture (MIT, 1979).
[18] CABAnAC, M., Plaisir ou déplaisir de la sensation thermique et homéothermie, Physiology and Behaviour, col. 4 (Pergamon Press) 1969 359364.

[19] Grivel, F., Barth, M. and Fraise, J.-P., L'influence du contexte situationnel sur diverses perceptions et évaluations de l'environnement physique, Bull. Psychol. XXXIII N ${ }^{\circ} 344$. 